\title{
Housing crisis: the Platform of Mortgage Victims (PAH) movement in Barcelona and innovations in governance
}

\author{
Julie DE WEERDT \\ Universitat de Barcelona \\ Avenida Diagonal 690 \\ 08034 Barcelona (Spain) \\ Julie.deweerdt@gmail.com \\ Marisol GARCIA \\ Universitat de Barcelona \\ Avenida Diagonal 690 \\ 08034 Barcelona (Spain) \\ Marisolgarcia@ub.edu
}

\begin{abstract}
This paper analyses the aftermath of the bursting of the housing bubble in Spain, which has left thousands of families without homes and indebted for life. In the first of two parts we look at contextually specific interactions between state regulation and marketoriented projects in Spain. This country is a salient case in which an economic recession and a debt crisis follow upon a long period of growth characterized by a housing bubble and a particular urban growth model. In this part we argue that the central government has played a key role in framing fiscal incentives for housing ownership, and local and regional administrations have engaged in short-term forms of inter-spatial competition for public and private resources, place marketing and regulatory under-cutting in order to attract investment. In the second part, the paper examines the urban social movement "Platform of Mortgage Victims" that, after starting in Barcelona, has spread to many other cities. The movement has created innovative strategies for housing accessibility and public and private governance in the housing market. These strategies include innovations at the local level and at national and European institutional levels. In this part we argue that social movements like the one we study are socially innovative when they aim at responding to social needs not met by the market and the state institutions. At the same time with their activism they transform the debate in the public sphere while prompting institutions to introduce new governance mechanisms and policy outcomes.
\end{abstract}

Key Words: Social innovation, housing crisis, multi-level governance, urban social movement 


\section{Housing crisis: the Platform of Mortgage Victims (PAH) movement in Barcelona and innovations in governance}

\section{Introduction}

This paper analyses the innovative strategies of an urban social movement created in response to the effects of the housing crisis. The bursting of the housing bubble in 2008 had a great impact on Spanish citizens. The PAH (Platform of Mortgage Victims) was founded in Barcelona in 2009, and spread rapidly all over Spain to cope with the social exclusionary dynamics of the crisis and respond to new needs. We look at PAH's actions from a social innovation perspective (Moulaert, et al., 2013) focussing on actors' innovative strategies and the governance innovation they introduce through dealing with victims of the housing crisis in Spain. The movement's strength and impact are closely related to the size of the housing bubble in each region and to the organizational capacity of its members. The strength and the success of the movement is also related to innovative collective strategies implemented by the leaders of the movement and the broad social base of the social action. We review the importance of homeownership in Spain and show the institutional and sociological factors accompanying the housing bubble and outline our analytical framework based on a social innovation approach. We then show the bottom-up and bottom-linked objectives and strategies of the PAH movement that influenced public opinion and brought changes in governance and discuss the particular innovative governance created in Barcelona. Finally, we include a brief media analysis of the impact of the movement.

\section{The case: research question and context}

The negative consequences of the housing-bubble burst in Spain greatly affected the population, especially house owners unable to pay off their mortgages due to widespread unemployment.

What collective social action emerged in cities in general and in Barcelona in particular? What were the institutional responses to bottom-up strategies? What internal and external governance developed in the movement against evictions?

\subsection{The Spanish housing property prevalence}

The housing property market was prominent in the Spanish economy since the 1960s. The interaction between the real estate market, welfare policies and family solidarity determined the country's current urbanization model. Rapidly changing sociological and economic factors made Spain into one of the largest homeownership countries in Europe: $85 \%$ of total housing stock in 2012 (CECODHAS, 2011). Several factors influenced the supply of housing over the last decades: demographic (boom generation accessing housing and high rate of international immigration), economic (investment returns and tourist industry), social (family solidarity) and cultural (second residence as a consumption pattern of upper and middle classes) (Garcia, 2010). By the 1990s the real estate sector was already important in the Spanish economy. However, the latest growth cycle (from the 1990s onwards) saw an acceleration of housing production combined with a long period of rising housing-prices linked to globalization factors (foreign 
investment, low interests rates and large demand fuelled by immigration) as well as an urbanization model based on high- and low-density supply and high demand for secondresidences partly linked to tourism.

The rapid urbanization growth model over the last few decades allowed Spain to compete with the biggest economies of the EUii. Financial deregulation and falling interest rates made mortgages accessible and resulted in more owner-occupied housing - a general trend observed all over Europe (CECODHAS, 2011). More than 6.5 million housing units were built in Spain during the economic boom.

Although housing production increased every year - four times more houses were produced in 2006 than in 1995 - and the number of new households did not increase proportionally, housing accessibility became more costly. Between 1998 and 2007 housing prices triplediii (Garcia Montalvo, 2009). Most of the housing production was intended for sale while the rental market decreased considerably since the 1950s. Also, social housing production - even though almost inexistent - was mostly intended for sale. This, together with a lack of incentives to ensure a stable and accessible rental market, left few options to those wanting to establish new households. Home ownership became a feature of the Spanish urban growth model, fixed by the time the housing bubble burst: $84.5 \%$, in comparison with only $12.2 \%$ of rental housing available $(2.3 \%$ other types) (Pareja-Eastway \& Varo, 2002).

\subsection{State incentives}

Regulations to protect tenants by freezing rents and make evictions difficult together with high inflation in mid $20^{\text {th }}$ century made it economically uninteresting to invest in rental real estate or for landlords to let and maintain buildings. In the 60s new regulations allowed the sale of houses and flats to long-term tenants at very low prices and incentivized new housing (Cabré \& Modenes, 2004). This, together with the inexistence of land use regulations stimulated real-estate investment which gradually led to the construction sector becoming an important factor in Spanish economic growth.

Two state-led policies further stoked the housing bubble. One concerned housing supply: Municipalities received tax benefits from housing production. On the demand side: fiscal incentives spurred families to buy housing. When finally regional and local governments drew up regulations to contain land speculation the urbanization process had already exploded.

Municipalities engaged in real estate boosterism, albeit to different degrees. Modifying land-use classifications attracted constructors and entrepreneurs to invest in their territories. In cities like Valencia this led to a "growth-machine" type of expansion centred on land valorisation and rent production. Elsewhere economic growth was accompanied by redistribution policies (foremost Barcelona and Bilbao). The ideology of urban policy stimulating urban competitiveness through attracting investments from the construction sector spread among cities, more so in Madrid and Valencia than in Barcelona and Bilbao (Díaz Orueta, 2012). 
Both conservative and social-democratic governments consolidated fiscal incentives for housing ownership from the reinstatement of democratic government (1976) until late 2012. Tax deduction for home-owners benefited buyers but also, and mainly, real-estate developers, builders and investors since this fiscal policy contributed indirectly housing price increases. Furthermore, public authorities in charge of housing promoted the purchase of real estate as a safe and good investment (Colau \& Alemany, 2012).

\subsection{The economic crisis: unemployment and housing evictions}

Economic expansion since the mid 1990s, centred on construction and real estate, yielded many new jobs. However, since the start of the crisis in late 2008 job destruction occurred at a similarly high rate as its earlier creation (European Commission, 2012). By the end of 2011 almost 2.5 million jobs were lost, more than 1.4 million in the construction industry.

Since the crisis began millions of citizens lost their jobs with many unable to pay their mortgage bills. What the "buyers-to-be-debtors" did not know - upon signing the mortgage loan - was that in case of default, besides expropriation and eviction, this would result into lifelong indebtedness, condemning them to poverty and social

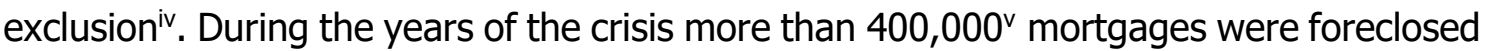
throughout Spain, affecting many thousands of households (see Figure 3). The effects of the housing bubble burst have been more visible involving stricken families but bankruptcies of real-estate companies had a much bigger impact on banking sector losses.

\subsection{European governance and crisis management}

European governance can be considered yet another factor in the recent housing crisis in Spain. Upon entering the euro area, Spain and other Southern European countries lost the possibility of devaluing their currency as an instrument to protect their domestic industries. Inflows of capital to these EU countries were supposed to promote a process of economic convergence with Northern countries. But in some countries they basically fuelled consumption and the growth of bubbles in asset prices. This was the case of Spain were the housing market and tourism grew dramatically. The construction firms also profited from many infrastructure project partly finance by EU Structural funds (Etxezarreta et al., 2011). While the housing market was exploding with a boom in real estate, industrial companies faced difficulties in keeping up with high prices. International competitiveness suffered. As a result the current account deficit grew from $3.9 \%$ of GDP in 2001 to $10 \%$ in 2007 . This deficit was financed by capital inflows, particularly loans from German and other foreign banks, made easier by the deregulation of the EU financial services sector. (Euromemorandum, 2013, 8-31).

With the financial crisis 2008 the money influx stopped for companies and families. This led to payment arrears by developers, builders and buyers. By the end of 2011 the index of non-performing housing related credits was $20.9 \%$ for developers, $17.7 \%$ for builders and $2.8 \%$ for buyers. Even if repossession from buyers increased as many of them lost their jobs, housing owners were not the main debtors. These were developers and builders, which made Spanish banks the largest real estate managers since the housing bubble burst. (Rodríguez López, El Pais, 9/6/2012). 
Governance changes were introduced in the EU in response to the crisis of government debts affecting countries that lost the confidence of the international financial markets. As the money influx stopped abruptly with the 2008 financial crisis in Southern European countries these EU changes involved a comprehensive system of tutelage with pressure for expenditure cuts in exchange for access to finance. The Spanish government officially asked for a European "bailout" for the Spanish banks to amounting 100.000 million Euros and received it on condition that the Spanish state would guarantee the return of the European credit. That is, the loan would directly increase Spanish government debt (Eurostat, 2012). In other words what was a private debt became a public debt to be paid by Spanish citizens. This transfer from private to public debt was, and is, accompanied by a strict austerity programme, not only involving an internal devaluation of workers' wages, a further expansion of job destruction in the private and public sectors, but also the retrenchment of the welfare state and social entitlements.

\subsection{Mortgage Legislation}

To understand the problem of over-indebtedness and housing eviction among Spanish citizens we need to refer to the norms regulating the eviction process and mortgage legislation. Over the years the Mortgage Law ${ }^{\text {vi }}$ was eased several times to boost the national economy and financial markets, leading to deregulation and more financial risk. For example, until March 2013, there was no maximum interest on arrears which led to cases of more than $30 \%$ interest rate. After the European Court of Justice ruling, the Spanish government had to adapt the legislation to European standards.

The Code of Civil Procedurevii which regulates the eviction process in case of nonpayment of debts creates an imbalance, protecting financial institutions more than individual debtors. The eviction process could start after only one month of arrears, and the financial institution could take over the property in an auction for minimum $50 \%$ of the initial taxation price (now changed to 60\%). This leaves the mortgagor with plenty to pay in order to settle the debt. Article 1911 of the Civil Procedure states that the debtor has to meet the debt with all his present and future goods. Until the recent adjustments in 2012 and 2013 the debtor could not defend himself in court during the eviction process viii (even when the mortgage contract contained abusive clauses), without any option for debt settlement or individual bankruptcy.

\section{The PAH movement: a social actor of bottom-up social innovation}

Bottom-up strategies leading to social innovation emerge when organized citizens who may disagree with mainstream policy implementations put forward alternative ways of addressing new risks not envisaged by public and market institutions. Two related issues need addressing: 1 ) the innovative processes to obtain resources to meet emerging and unsatisfied social needs, and 2) the way these processes can lead to a transformation of governance mechanisms, with possible changes in power relations in areas that deal with social exclusion dynamics (Pradel, et al., 2013, 156). 
Bottom-up strategies often remain local and only reach the level of municipal governance structures. The actors of such strategies have limited networking capacity, cannot engage a wider public, or reach regional and national administrations. How much different kinds of actors engaged in social innovation can influence policy in a multi-level context is an open question, subject to empirical analysis (García 2006; Moulaert et al. 2007). In the case of PAH there was rapid growth from a small group of citizens, organized around housingix and other social issues, to a large movement capable of changing the framework surrounding the eviction problem, while creating nation-wide awareness of this social injustice. The PAH resembles a social movement dealing with grievances ${ }^{x}$ affecting people who cannot meet their mortgage obligations and are evicted from their homes while still having to pay the accumulated debt.

We first analyse the PAH as a social movement with its objective, strategies and campaigns. We then look at it as a socially innovative actor and analyse its internal and external governance relations. Lastly we discuss the impacts the mobilization has had on governance processes and how it inspired other innovative initiatives.

\section{Figure 1. Analytical frame}

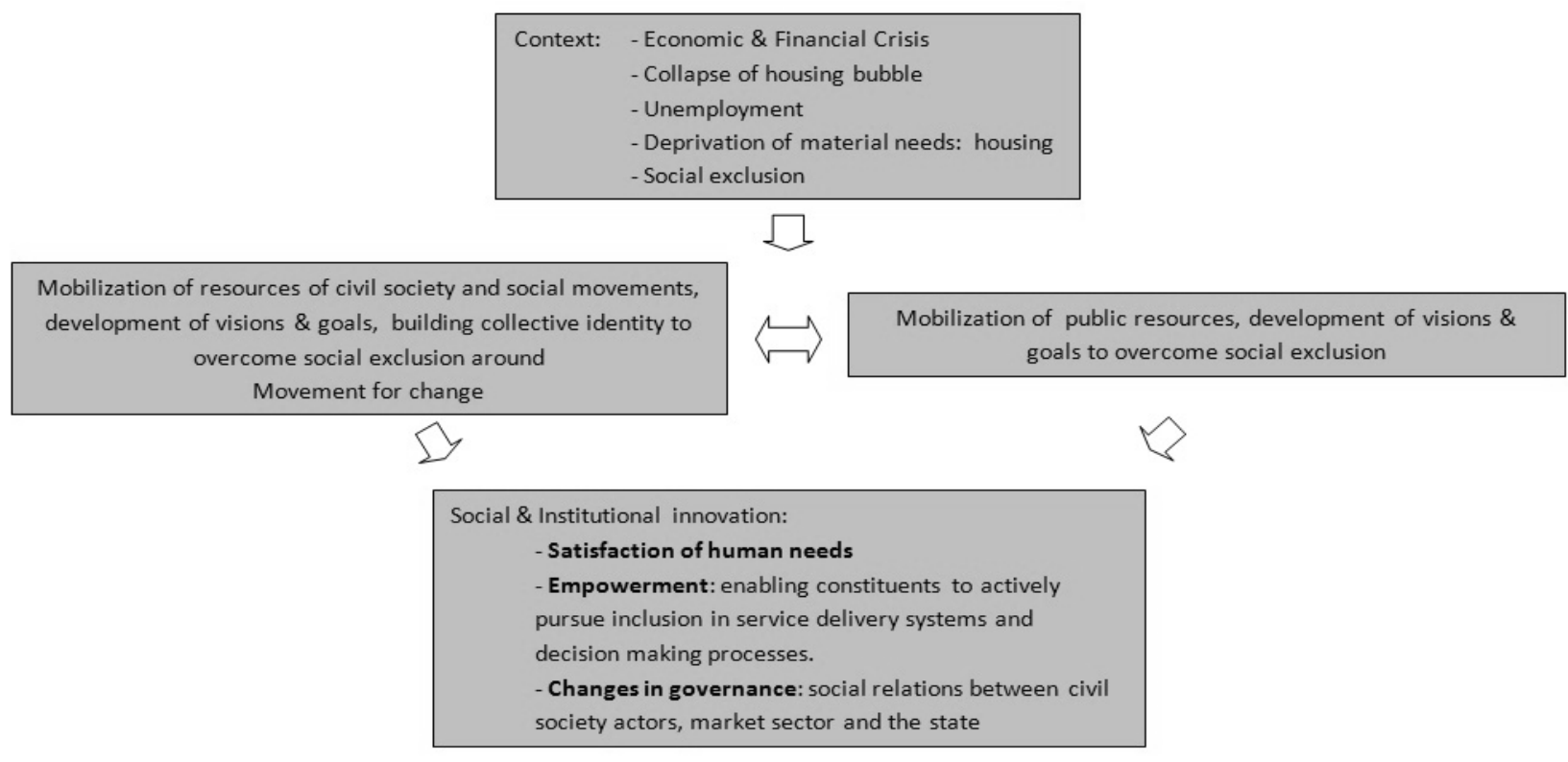

Based on Moulaert et al. (2007)

The proposed analytical frame includes: (a) the context (economic and financial crisis; collapse of the housing bubble; high unemployment; deprivation of housing and a process of social exclusion; (b) mobilization of resources by civil-society actors and public institutions; (c) the resulting social and institutional innovation involving satisfaction of the need for housing, empowerment of people affected by the mortgage crisis and changes in governance as a result of civil-society and institutional action. This social and institutional innovation can lead to "bottom-linked" innovation.

\subsection{Methodology}


Our analysis is based on statistics from EUROSTAT, the Centre of Sociological Research (CIS), the National Institute of Statistics and Judiciary statistics. We also rely on participant observation, 10 semi-structured interviews with stakeholders and public institutions officials, our own elaboration of a database on media attention, attendance at $\mathrm{PAH}$ reunions, on-line documents of the $\mathrm{PAH}$, protocols and data of eviction cases. In addition, a local Stake-holders workshop ${ }^{\mathrm{xi}}$ was organized gathering representatives of various social and institutional initiatives and other housing stakeholders. Empirical research was done between April and September 2013.

\subsection{The rise and expansion of the Platform of Mortgage Victims (PAH)}

After its 2009 emergence in Barcelona, the PAH gradually spread to other cities of the Barcelona region and the rest of Spain reaching 10 local platforms by mid-2011. In May of that year, after the 15M mobilizations and the start of the "Indignados" movement, the PAH started growing exponentially throughout Spain, reaching 144 platforms in spring 2013 and 205 early 2014.

The PAH became a social movement capable of influencing public opinion and of providing innovative collective strategies, such as collective re-negotiation of mortgage debts with financial institutions to support affected families. By 2013 the movement covered all 17 regions (Autonomous Communities) of Spain. It is organized horizontally with local divisions and representatives meeting and acting locally. Each Autonomous Community has at least 1 local platform with many more in Catalonia and Valencia (Figure 2). This reflects how the movement expanded from its early roots in Barcelona throughout the rest of the country. The density of platforms in an area correlates with the evictions occurring in that area. Where the crisis was acute (the areas where the housing bubble was bigger: the Mediterranean coastline), more platforms were developed (see Figure 3).

Figure 2. Number of local Platforms per Region. 2013

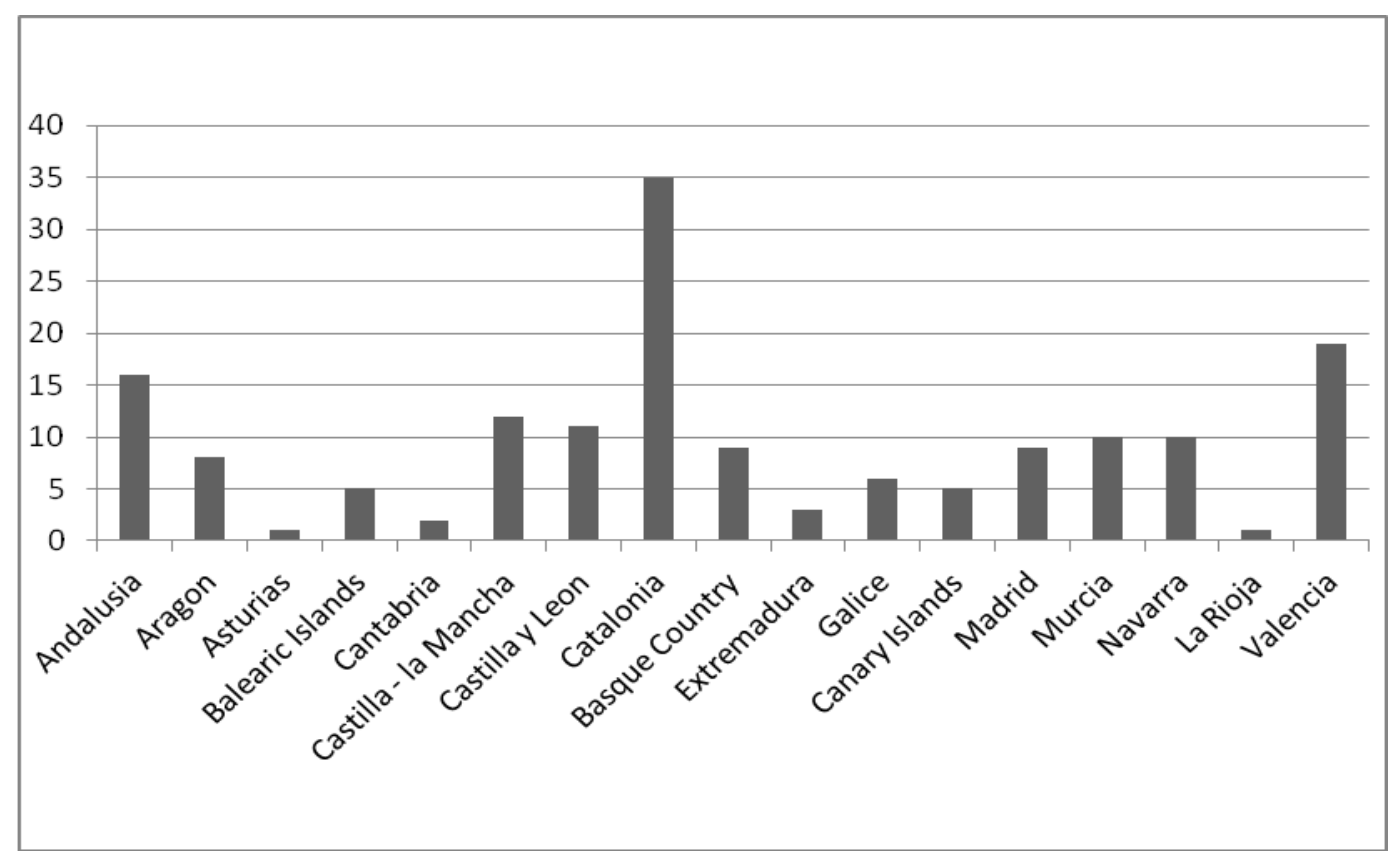




\section{Figure 3. Housing evictions, Mortgage foreclosures \& Empty dwellings per} Autonomous Community

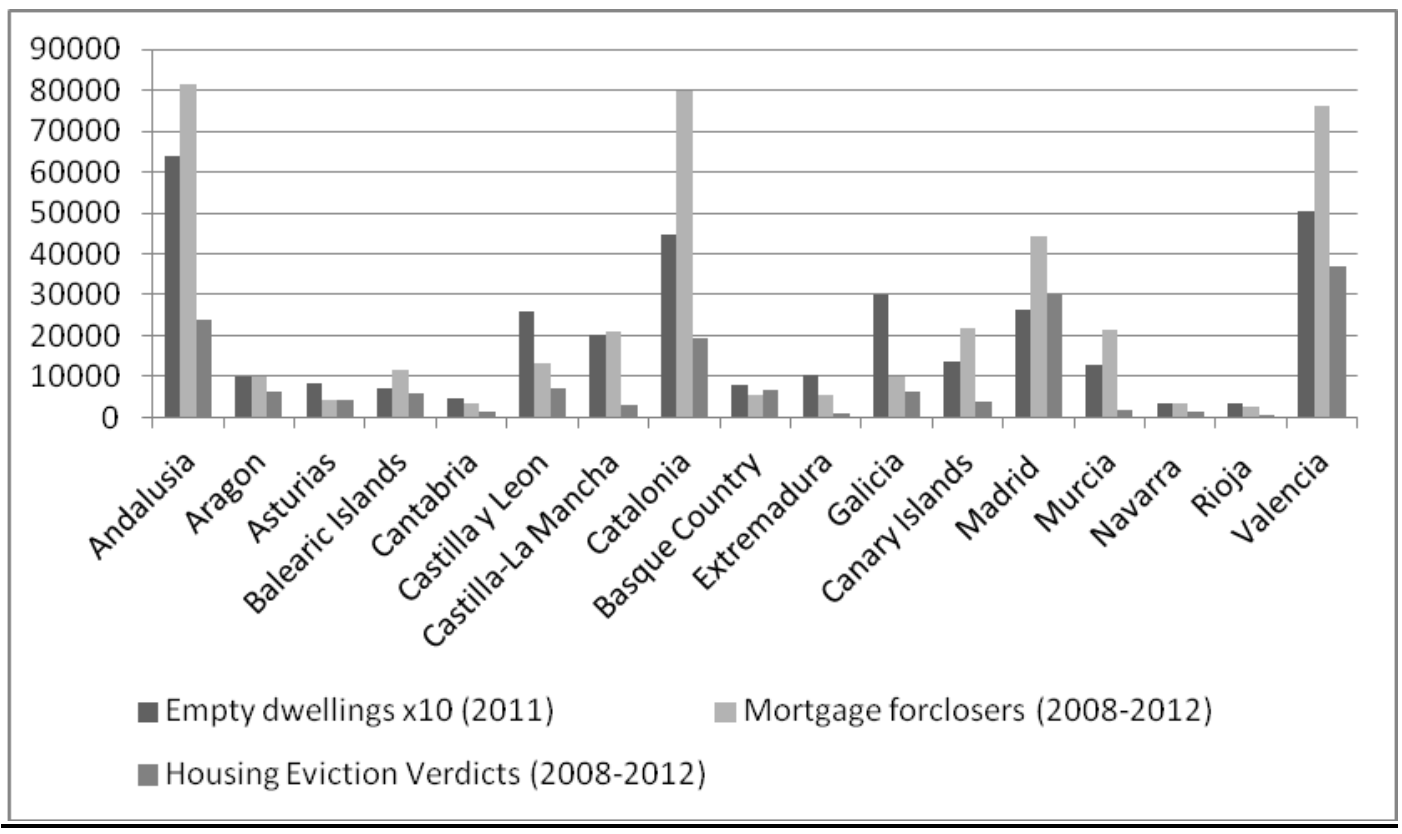

Source: authors' elaboration with data from INE and Judiciary Statistics ${ }^{\text {xii }}$

In Catalonia the locally organized platforms meet regularly in assemblies where they offer collective advice and support. Members of the platforms explain and lecture on the eviction process in public gatherings while emphasizing values of mutual support and solidarity. The concerns of whoever approaches them with a housing eviction problem are discussed publicly. Every platform has a webpage or Facebook group to communicate their actions, and to share information and documents for use in fighting the eviction process in court or in the financial institution.

One strength of the PAH movement is its capacity to capture media attention. It gains visibility as a movement and more importantly makes visible the tragedy of hundreds of thousands of families that are threatened with losing their homes. In this way it managed to transform what was originally conceptualised by financial institutions as individual problems into a collective issue (Colau \& Alemany, 2012) going beyond (upscaled) the local and national territory and reaching the European scale. More on this later

\subsection{The PAH as an innovative actor: Strategies \& Objectives}

The Platform of Mortgage Victims empowers people through innovative actions based on solidarity. It fights recent exclusionary dynamics of financial and material deprivation resulting from the housing crisis by giving them instruments to respond to the threats from financial, judiciary and government institutions. Financial institutions are forced into debt renegotiation, communication with the debtors and even debt settlement. By thoroughly investigating the judicial eviction process and the Mortgage law the PAH has elaborated documents and ready-to-use forms to oblige targeted 
institutions into debt mediation. By organising collectively they can exert pressure on the multiple actors involved in the eviction process such as legislative bodies and other institutions at local, regional and even international level.

In general PAH strives to change practices through a temporary suspension of evictions and through a change in the law regulating payment in kind (by returning the house to the bank). It pressures private and public institutions to augment the rental social-housing stock, for example by transforming evicted apartments or empty building blocks into social housing. Currently only $2 \%$ of the total housing stock is intended for social rents (CECODHAS, 2011): largely insufficient to satisfy demand.

One PAH objective was always to find out how evictions are affecting the population and bring this problematic to public attention. They wanted to create awareness among Spanish citizens and institutions that the debt problems experienced in Spanish households are not the result of individual failure but a consequence of decades of housing politics and financial and economic decisions. Their actions in the public sphere comprised mass protests against government institutions at local, regional and national level. Financial institutions were also targeted with demonstrations and actions. In this way PAH managed to acquire visibility and reputation among most of the Spanish population by the end of 2012. In March 2013 the movement enjoyed the support of $81 \%$ of the Spaniards ${ }^{\mathrm{xiv}}$ whereas only $10 \% \mathrm{xv}^{\mathrm{xv}}$ of the population reported trusting the government system.

Beyond raising awareness and functioning as a protest movement, the $\mathrm{PAH}$ developed innovative strategies and actions to respond practically to the housing crisis. It organizes and develops services and documents to meet the newly arisen social needs: providing knowledge on the eviction process, tools for debt negotiation, mutual support in situations of distress. When someone is evicted, for example, the adherents of the local platform will block the entrance of the home-to-be-evicted in order to stop or postpone the eviction and to gain time for negotiation with the financial institution. Through sharing knowledge and experience of the eviction process during the weekly collective advice assemblies people are empowered through information exchange and guidance during the eviction process. Furthermore, accessible documents to enforce a revision of the mortgage contract are provided and, most importantly, victims will find support and recognition from people experiencing similar debt issues. Another innovative way to resist the pressure of financial institutions are the collective negotiation groups organized per financial institution - to exert joint pressure in the renegotiation of mortgage contracts, to enforce payment in kind or a social rent. If eviction cannot be prevented and the victims cannot find alternative housing through social services or with relatives, they can be lodged in one of the blocks occupied by the PAH. The occupation of empty building blocks accompanied a well-thought-out campaign pressuring the government to meet the enormous need for social housing and oblige financial institutions to offer their empty buildings for rent. The occupation of these buildings is, in addition to its housing function, used as a pressure instrument in negotiations with the financial institution (owner of the building) to obtain legal contracts of social rent for families needing housing. In this way the PAH tries to secure its ultimate goal: 
satisfaction of the human need for housing. In February 2014, 8 months after the start of the collective occupation of building blocks, 20 blocks were occupied, sheltering 1049 people.

At the local level the PAH started cooperating with lawyers elaborating a proposal to modify the Mortgage Law and the Code on Civil Procedure seeking to redress the imbalance between individual debtors and financial institutions. In 2010 the local platform in Barcelona presented, with the support of the Defence Committee of the college of Lawyers of Barcelona and other civil society actors, this motion to the city council. Some left-wing political parties expressed their interest ${ }^{x v i}$ and gradually more local platforms started presenting these motions to their municipalities.

\subsection{PAH social action at other geographical scales}

The PAH has also urged legislation for structural changes in housing politics. Institutions at different levels of governance are challenged to declare themselves and take a position on the practices of forced eviction and mortgage foreclosures.

In Catalonia, a new motion was prepared in 2014, based on the regional legislation on Right to Housing xvii, providing legal grounds to municipalities and Autonomous Community governments to fine financial institutions for vacant housing

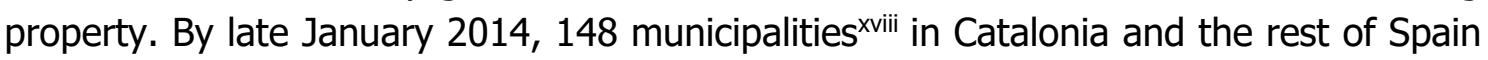
had signed these motions, openly supporting the PAH and thereby disputing the political legitimacy of the national government. Some municipalities have started actions themselves by pressuring financial institutions or suspending the value added tax in cases of accord and satisfaction agreements over the mortgaged good. Regionally the most ambitious initiative so far (May 2013) belongs to the Andalusian parliament ${ }^{\mathrm{xix}}$.

To reshape national legislation the PAH started the People's Legislative Initiative (ILP). Mobilizations started in February 2012 and one year later had collected almost triple the officially required number of signatures $(1,402,854)$ to propose legislation, reflecting the wide support and visibility the PAH gained during the ILP campaign. This coincided with the organization of their controversial "escraches": protests staged outside the homes of politicians, and with the ruling of European Court of Justice on the legitimacy of the Spanish mortgage legislation. Also in this period - February and April 2013 - the charismatic leader of the PAH was invited to talk in both the Spanish Chamber of Deputies and the European Commission. These events yielded extensive media attention on the precarious situation of the Spanish mortgage debtors and the impossibility for individuals to plead their case in court, even though the contracts often contained abusive clauses.

The ILP demands halting people's forced evictions as long as authorities do not provide alternative housing for them. Secondly it requests changing legislation to make possible payment of the remaining mortgage debt in kind (by handing over the house) and thereby allowing the former homeowners to stay in the property paying a social rent. During the ILP campaign, two law amendments were implemented. The first one in November 2012, prescribing the temporary suspension of evictions of families 
considered as particularly vulnerable ${ }^{x x}$. The second one ${ }^{x x i}$, in May 2013, under pressure of the ILP and the judgment of the European Court of Justice, allows debtors to defend their case in court in the case of abusive clauses in the mortgage contract. It limits the maximum interest on arrears, extends the period for starting the mortgage eviction from one to three months of delayed payment and recommends the creation of 6000 social housing units. Clearly, these law amendments remain minimal and only under very strict and extreme conditions is debt settlement allowed. However, this legal change and the internationalization (up-scaling) of the problem have led to some social innovation in power relations between mortgage debtors and creditors.

Table 1. Strategies, Campaigns, Scales of Action and type of Mobilization

\begin{tabular}{|c|c|c|c|}
\hline $\begin{array}{l}\text { Movement } \\
\text { Strategies }\end{array}$ & Action Repertoire & Territorial Level & Confrontational \\
\hline \multirow{6}{*}{$\begin{array}{l}\text { Influence Public } \\
\text { Opinion \& } \\
\text { Visibility }\end{array}$} & Traditional Media Attention & National - Regional & no \\
\hline & Posters & Neighbourhood & no \\
\hline & Demonstrations & National - Regional - Municipal & yes \\
\hline & Documentaries & National & no \\
\hline & $\begin{array}{l}\text { Mass-self Communication \& } \\
\text { Self-Mediation }\end{array}$ & International - National - Local & no \\
\hline & Website & National - Municipal & no \\
\hline $\begin{array}{l}\text { Mobilizing } \\
\text { Constituents }\end{array}$ & Multi-media \& Assemblies & Neighbourhood & no \\
\hline \multirow{4}{*}{ Protest } & $\begin{array}{l}\text { Blockade entrance house for } \\
\text { stopping evictions }\end{array}$ & Neighbourhood & yes \\
\hline & Demonstrations & Municipal & yes \\
\hline & Mass-self Communication & National & yes \\
\hline & Occupying & Municipal & yes \\
\hline \multirow{2}{*}{$\begin{array}{l}\text { Collective } \\
\text { Negotiation with } \\
\text { banks }\end{array}$} & $\begin{array}{l}\text { Occupation of offices \& Read } \\
\text { Manifest }\end{array}$ & Municipal & yes \\
\hline & Bundle Cases & Municipal & no \\
\hline \multirow{6}{*}{ "Escraches" } & $\begin{array}{l}\text { Demonstration in front of } \\
\text { politicians' homes }\end{array}$ & Neighbourhood & yes \\
\hline & $\begin{array}{l}\text { Read Manifest - stories of } \\
\text { affected }\end{array}$ & Neighbourhood & no \\
\hline & Placemaking: stickers & Neighbourhood & no \\
\hline & Letters to Politicians & National & no \\
\hline & Media attention & National & no \\
\hline & Mass-self Communication & National & no \\
\hline \multirow{2}{*}{ Law Change (ILP) } & Signatures & National & no \\
\hline & Demonstrations & National & yes \\
\hline \multirow{4}{*}{$\begin{array}{l}\text { Interaction with } \\
\text { public institutions }\end{array}$} & Motions & Municipal & no \\
\hline & & Regional & no \\
\hline & $\begin{array}{l}\text { Participation in roundtable } \\
\text { housing }\end{array}$ & Municipal & no \\
\hline & Collective Advice Assemblies & Municipal & no \\
\hline
\end{tabular}




\begin{tabular}{|l|llc|}
$\begin{array}{l}\text { Empowerment of } \\
\text { citizens }\end{array}$ & $\begin{array}{l}\text { Tutored negotiation with } \\
\text { bank }\end{array}$ & Municipal & no \\
\hline $\begin{array}{l}\text { Social Housing } \\
\text { acquisition }\end{array}$ & Squatting & Municipal & yes \\
\hline & $\begin{array}{l}\text { Negotiation with banks } \\
\text { Source: Author's elaboration with data from interviews, participant observation and PAH website }\end{array}$ \\
\hline
\end{tabular}

\subsection{Visibility: impacts on media and public opinion}

The PAH was formed in February 2009, but it took two years to gain media notice. The emergence of the 15M movement and the simultaneous demonstrations in 50 Spanish cities on the $15^{\text {th }}$ of May 2011 was the turning point for the PAH. They were regularly mentioned in the news and caught the attention of the wider population. The following chart shows the media coverage given to the mortgage payment problems and evictions related to the PAH in the national newspaper EL PAIS, selected for its widest media impact.

Figure 4: Media Coverage on PAH in El País

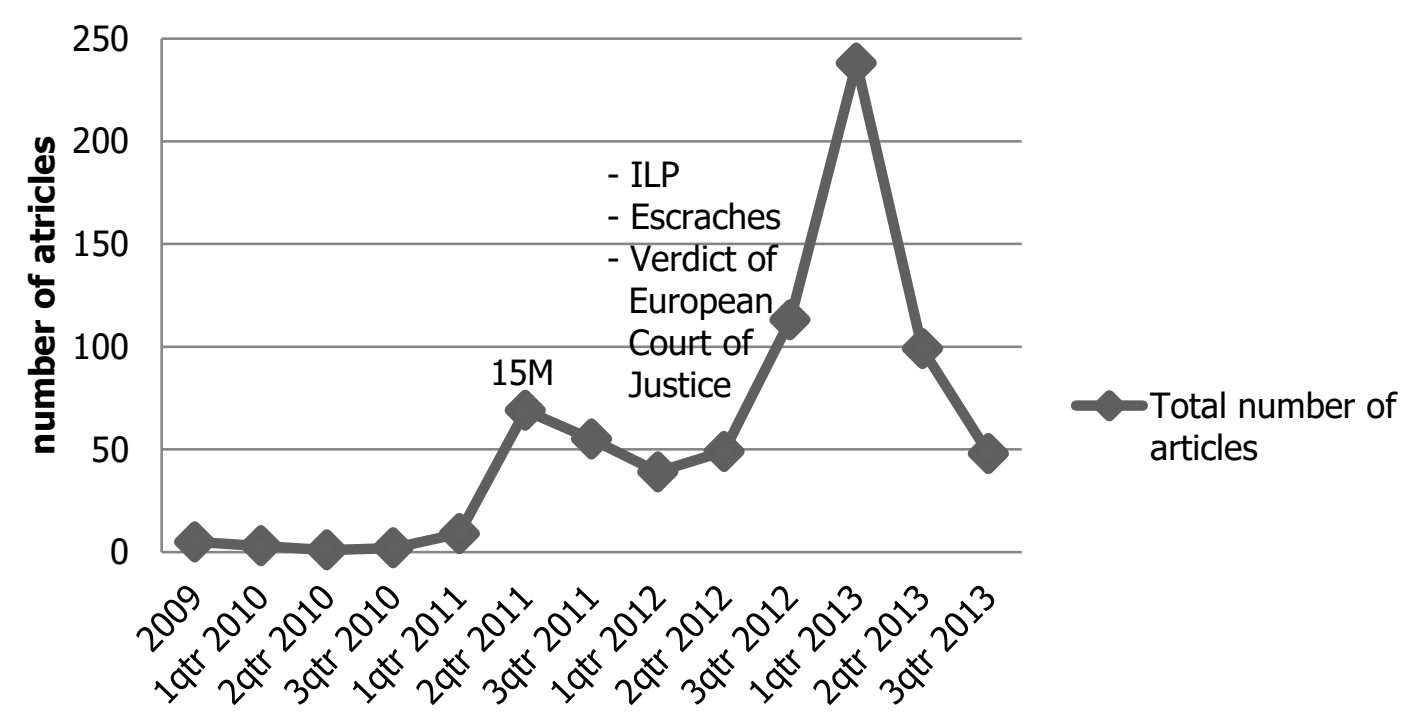

Source: Elaboration of authors with data collected from newspaper articles "El Pais" (From 8/02/2012 onwards all articles published online are also taken into consideration)

With the start of the People's Legislative Initiative and the related mobilizations, media attention started rising exponentially in the second quarter of 2012. This period coincides with the mobilizations and reports on the first anniversary of the $15 \mathrm{M}$, the appearance of the charismatic leader of the PAH in the Chamber of Deputies and the verdict of the European Court of Justice on the Spanish mortgage legislation. The PAH was breaking news.

Increased media attention induced ever more people to reach out to PAH for help and support. The movement grew in numbers, in the respect it commands and in negotiating power. The national government tried to destabilize the movement through a criminalization of the "escraches" (protests staged outside the homes of politicians). However, accusations against the movement were not well received by the public and 
attempts to weaken the power of the PAH failed. Instead, polls indicate that $81 \%$ of the population supported the actions of the PAH in this period (metroscopia, 2013).

\section{Figure 5: Media Coverage Devided by Topic}

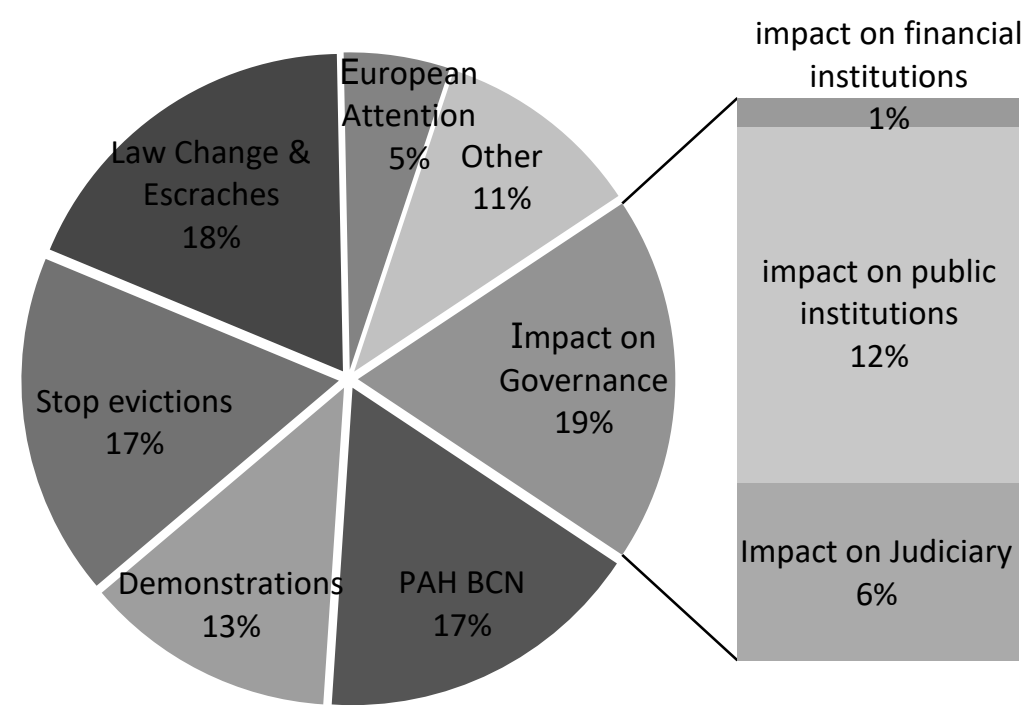

Source: Elaboration of authors with data collected from newspaper articles "El Pais"'xxii

The media mainly (48\%) covered actions of civil disobedience, i.e. confrontational events such as the "Stop evictions" campaign in which adherents gathered in front of the home-to-be-evicted, the "escraches", occupations of the seats of financial institutions or other demonstrations. Very rarely did articles concern the organisation of the social movement, collective-advice assemblies, efforts behind the scenes or less spectacular actions such as collective negotiations with financial institutions. $19 \%$ of media coverage was on the impacts on governance institutions (see below).

The broad media coverage of the platform and its actions contributed to its reputation, the acquisition of a very broad support base and augmented its negotiation power and legitimacy. This presence in the news allowed an impact on multiple levels of governance beyond the local level.

\section{Innovation and governance: internal and external relations}

Here we examine how the PAH organizes internally and how the platform developed relations with other organizations and institutions. The social base of the PAH consists mainly of citizens affected by the mortgage problem. Only a core group has not experienced a financial housing problem. The majority of members are adults, employed until recently, but having lost their jobs and with modest income.

The PAH is a horizontally organized urban movement that regularly discusses actions in assemblies. Core groups meet several times a week to discuss strategies and 
actions. Open assemblies also happen weekly, where people newly affected by mortgage problems can join the veterans. Individual experiences are shared publicly and answered with advice and human support. The core group and the veterans help the newcomers and socialise them into the dynamics of the organization.

\section{Table 2 : PAH-Barcelona Internal organisation}

\begin{tabular}{|c|c|}
\hline \multirow{5}{*}{ Support Base } & "Deprived" Citizens (financial stress, housing problem) \\
\hline & Age constitution: adults over 25 \\
\hline & Socio-economic class: low and middle class \\
\hline & Adherents to the movement \\
\hline & Personal Benefit: reciprocity, solidarity \\
\hline \multicolumn{2}{|c|}{ Nuclear Group Dedicated, involved members and others experiencing financial stress } \\
\hline \multirow{3}{*}{ Resources } & Labour: Mostly unemployed with time to participate \\
\hline & $\begin{array}{l}\text { Money: Own fund-raising, Individual Donations, Donations Observatory } \\
\text { DESC }\end{array}$ \\
\hline & Legitimacy: High citizen support \\
\hline \multirow{4}{*}{$\begin{array}{l}\text { Network } \\
\text { Structure }\end{array}$} & Horizontal \\
\hline & Professionalization \\
\hline & Spokesperson: (charismatic woman) \\
\hline & Subgroups in charge of different actions \\
\hline \multirow{3}{*}{$\begin{array}{l}\text { Decision } \\
\text { Making }\end{array}$} & Consensus by Assembly: no voting \\
\hline & Representatives in regional and federal meetings \\
\hline & Leaderless: rotation of Responsibilities, full involvement of everybody \\
\hline
\end{tabular}

PAH external relations are of two types: relations with private and civil society organisations and relations with public institutions (tables 3 and 4). PAH collaborates with some significant civil society groups in Barcelona. Below we will explain further how the strong ties with these associations are strategically used to obtain access to information and other resourses throughout these networks. These associations offer support to the Platform as a whole and to individual members. The relationship with financial institutions is conflictive. However, agreements are reached in particular instances between the PAH and bank managers to renegotiate debts or even condone debts.

Table 3. PAH-Barcelona External relations with Private and Civil Society organisations

\begin{tabular}{c|c|c|c|c|c}
$\begin{array}{c}\text { Private \& Civil } \\
\text { Society }\end{array}$ & Territorial Level & $\begin{array}{c}\text { strength of } \\
\text { ties }\end{array}$ & Collaboration & Conflict & Constraining/Supportive \\
\cline { 2 - 6 } $\begin{array}{c}\text { FAVB (Federation } \\
\text { Neighbourhood }\end{array}$ & Municipal & high & high & no & Supportive \\
$\begin{array}{c}\text { Association BCN) } \\
\text { Observatory DESC } \\
\text { (Social, Economical }\end{array}$ & Municipal & high & high & no & Supportive \\
\cline { 3 - 6 }
\end{tabular}




\begin{tabular}{|c|c|c|c|c|c|}
\hline $\begin{array}{c}\text { and Cultural rights } \\
\text { Association) }\end{array}$ & & & & & \\
\hline Labour Unions & National & low & no & no & \\
\hline $\begin{array}{c}\text { Other Social } \\
\text { movements } \\
\text { (iaio flautas, DRY, } \\
\text { auditoria de la } \\
\text { deuda y } 15 \mathrm{M} \text { ) }\end{array}$ & National & medium & medium & no & Supportive \\
\hline Caritas & $\begin{array}{c}\text { National \& } \\
\text { Municipal }\end{array}$ & low & no & no & \\
\hline $\begin{array}{c}\text { Financial } \\
\text { Institutions }\end{array}$ & $\begin{array}{c}\text { National \& } \\
\text { Municipal }\end{array}$ & low & no & yes & Constraining \\
\hline
\end{tabular}

Table 4. PAH External relations with public institutions

\begin{tabular}{|c|c|c|c|c|c|}
\hline $\begin{array}{c}\text { Public } \\
\text { Institutions }\end{array}$ & $\begin{array}{c}\text { Territorial } \\
\text { Level }\end{array}$ & $\begin{array}{c}\text { Strength of } \\
\text { ties }\end{array}$ & Cooperation & Conflict & $\begin{array}{l}\text { Constraining } \\
\text { /Supportive }\end{array}$ \\
\hline Ofideuta Barcelona & Regional & low & no & no & \\
\hline $\begin{array}{l}\text { "Table Housing } \\
\text { Barcelona" }\end{array}$ & Municipal & medium & low & no & \\
\hline Municipal Council & Municipal & low & no & $\mathrm{No} / \ldots$ & Constraining \\
\hline Catalan Government & Regional & low & no & no & Constraining \\
\hline $\begin{array}{c}\text { National } \\
\text { Government* }\end{array}$ & National & low & no & Yes & Constraining \\
\hline Judiciary * & National & medium & medium & Diminishing & Supportive \\
\hline $\begin{array}{c}\text { European Court of } \\
\text { Justice* }\end{array}$ & European & low & low & no & Supportive \\
\hline
\end{tabular}

\section{Impact on governance: Innovative initiatives.}

Public administrations, civil society organisations and social movements react variously to the newly arisen social needs: knowledge about mortgage contracts and legislation, information on the rights and responsibilities of people with housing problems, advice and assistance in negotiation with financial institutions. It is important to emphasise that the actions of the "Platform of the Affected by the Mortgages" have brought a shift in public opinion on the problem of mortgage foreclosures and housing evictions, reaching their maximum impact in March 2013. The situation of more than 415,000 mortgage foreclosures in 2008-2012 period; 244,500 initiations of housing evictions, with almost 160,000 executed, is now acknowledged as a social issue that requires policy intervention. 
In Barcelona a new governance frame has been developed by regional and local institutions creating a web of organizations, ad-hoc programmes and multi-level interactions. Here we briefly introduce the most salient organizations and initiatives that constitute innovation in governance without claiming that these innovations are a direct result of PAH's social campaigns. However, how public institutions and civil society organizations are creating new forms of coordination to cope with housing issues in the wake of the mortgage crisis cannot be disconnected from the strong social and media pressure created by the PAH movement.

\subsection{Public actors and actions}

\subsubsection{Autonomous Community of Catalonia:" Ofideute"}

In 2010 the Autonomous Community of Catalonia started a mortgage debt counselling service to respond to the social exclusionary dynamics caused by the crisis ${ }^{x x i i i}$. "Ofideute" evolved from a small team providing support in the Barcelona office, to a well known entity found all over Catalonia. Its main objective is keeping indebted families from ending up homeless. Ofideute is innovative in having established informal agreements with financial institutions to have their risk departments connect with a debt mediation service of the public administration, thereby establishing a communication channel on mortgage problems of vulnerable consumers ${ }^{\text {xxiv }}$. Ofideute's role is close to Caritas' whose head of the mediation service is the same person who initiated Ofideute in $2010^{x \times v}$.

\subsubsection{Provincial administration: Mediation Service in Housing Debts (SIDH)}

This initiative of the provincial administration Diputació of Barcelona serves to advise and support municipal governments. The Social Services department of the Diputació offers judicial advice to people without resources on the principle that every citizen is entitled to social assistance and social integration. The strength of this service, as that of Ofideute, lies in coordination. It offers a communication/mediation channel between the financial institution and the individual ${ }^{\mathrm{xxv}}$. Partnership agreements were established with 27 municipalities of the Barcelona region covered by the Diputació. Governance based on institutional cooperation in Diputació also involved the housing and Juridical Service Orientation departments in the form of a new mediation service on housing debts partly using the existing infrastructure of the former Service of Judicial Orientation (SOJ). Communication also flows between this organism and the leading members of PAH and of Caritas.

\subsubsection{Municipal level: Advisory Board on Social Housing ("Consell de 'I Habitatge Social de Barcelona")}

The Advice Board on Social Housing ${ }^{x x v i i}$ (ABSH) emerged from one of the thematic boards of the "Consell de la Ciutatxviii": the participatory organ of the municipality of Barcelona. The ABSH formed in 2007 within the framework of the "Consorci de I'habitatge de Barcelona": the municipality's and the autonomous community's overarching body on housing at the municipal level. The ABSH was designed to function as a participatory and consultative structure concerning all issues of housing policy in Barcelona. It 
encourages participation of different stakeholders ${ }^{x x i x}$ in housing issues: civil society organizations, private institutions managing social housing services, etc. The Observatory DESC, which collaborates closely with the PAH, is member of the ABSH, as is the FAVB (Federation of Neighbourhood Associations of Barcelona). Also, the ombudswoman is always invited and informed as a visiting member of the Board.

\subsubsection{Municipal Government of Barcelona -" Servicio Asesoramiento"}

Barcelona municipality has reacted in multiple ways to the housing crisis. It has created a new coordination function involving different departments (social services and the housing area). Within mediation the municipality there are forty offices of Social Services and ten offices of housing where people with housing problems are attended. They have organized their own service between owners and tenants. In some cases financial help makes rent more accessible for tenants, to pay deposits or deal with accumulated debt. Some kind of social rent is created through subvention of the private rental market ${ }^{\mathrm{x} x \mathrm{x}}$.

The most innovative initiative of the municipality of Barcelona, supported and promoted by the ABSH, was to form the Mixed Commission on Housing Evictions in February 2011. The formation of this commission was an important political act, because through this the municipality acknowledges the existence of a structural problem of housing eviction, both rental and property-related, and of social-exclusion dynamics due to the financial crisis. The PAH is an official member of this Mixed Commission. This is the only innovative participatory commission of the municipality of Barcelona that officially includes the social movement, an example of innovative governance ${ }^{x x x i}$.

\subsection{Innovative initiatives: Caritas and Civil Society Actors}

\subsubsection{Caritas' Mediation Service in Housing}

In September 2011 Caritas started the Mediation Service in Housing (MSH). Caritas mostly runs on individual donations and with volunteers. These funds serve to give financial support to households in need. Until June 2013 Caritas owned 250 buildings acquired with multiple resources. Caritas established a communication channel with financial institutions. This link consists in an agreement with the financial institutions that they will cooperate and keep the communication open on all the cases of mortgage troubles of socially excluded groups. For Caritas a case is solved when it succeeds in renegotiating the mortgage debt, people can stay in their houses with a social rent or reach an accord of payment in kind.

\subsubsection{Federation of Neighbourhood Associations (FAVB) "Servicio de Mediación"}

The FAVB brings together over 100 neighbourhood organisations in Barcelona. On collective housing issues they search for solutions through cooperating with social movements and civil society organisations: Laio Flautas, 500*20 15M, Caritas and the $\mathrm{PAH}$, all concerned with the deprivation dynamics of the crisis. FAVB members have organized their own mediation service where people are attended individually by a lawyer and expert in mediation. 


\subsubsection{Observatory DESC}

Key members of Observatory DESC overlap with PAH. The Observatory is an umbrella organisation that gathers multiple organisations active in economic, social and cultural rights. They produce vital knowledge and conduct research useful for the PAH movement. The unofficial but strong link between key actors of the PAH and employees of the DESC ensures a network and creates a bottom-link towards (public) institutions. This clear strategy makes it possible for the social movement to remain their confrontational attitude towards public institutions and yet ensure a relation or information flow with institutions through the Observatory DESC.

\subsection{Other institutions and governance arrangements:}

\subsubsection{Ombudsman office}

The national ombudswoman presented a report on the "Economic Crisis and mortgage debts $^{\mathrm{xxxii} "}$ in January 2012. She proposed establishing regulations on insolvency of natural persons following the practice of most European countries. The report recommended that the government should provide a rule that allows "bona fide" debtors to remain in their property paying a rent according to circumstances. There should be a limitation on the interest on arrears - written into law in 2013, after the verdict of the ECJ.

The Catalonian ombudsman made further recommendations to the regional government on housing matters ${ }^{x x i i i}$, e.g. a free system of restructuration of debts ${ }^{\text {xxiv }}$ managed by a public entity which will establish a personalized plan, in agreement with the creditor, in order to pay off the obligatory debts. Until an agreement is reached, the debtor should not be evicted from his property. The Catalan Ombudsman insists that $30 \%$ of housing units be destined for social rent.

\subsection{PAH and bottom-linked innovation}

So far we have described the strength of the PAH movement and the actions of public institutions in the housing crisis particularly in Barcelona. Here we signal the tension between the different actors involved. We have been arguing that the PAH is an important bottom-up organization in multi-level governance through its social innovation capacity and its networks. The PAH movement has acted politically through stressing the need to democratize public institutions as well as claiming access to housing as a social and human right. Some actions by the PAH (e.g. occupation of buildings) have led some public and private housing managers to consider the movement and its claims as radical. Despite tensions between the PAH and public bodies there has been some cooperation, in instances of "bottom-linked" innovation. "Bottom-linked" innovation means the involvement of institutions that enables and sustains citizens' practices and guarantees citizen rights (Pradel et al., 2013). The "bottom-linked" concept is different from either bottom-up or top-down, in that the actors involved on either side of the divide come to arrangements to solve the problem at hand. In Figure 6 we present the web of organizations which cooperate to support the mortgage victims. Either directly or through the DESC members of the PAH movement talk and cooperate or enter into 
dialogue with other associations and with local institutions, thus establishing "bottomlinked" social innovation.

\section{Figure 6. Web of organizations dealing with the housing crisis}

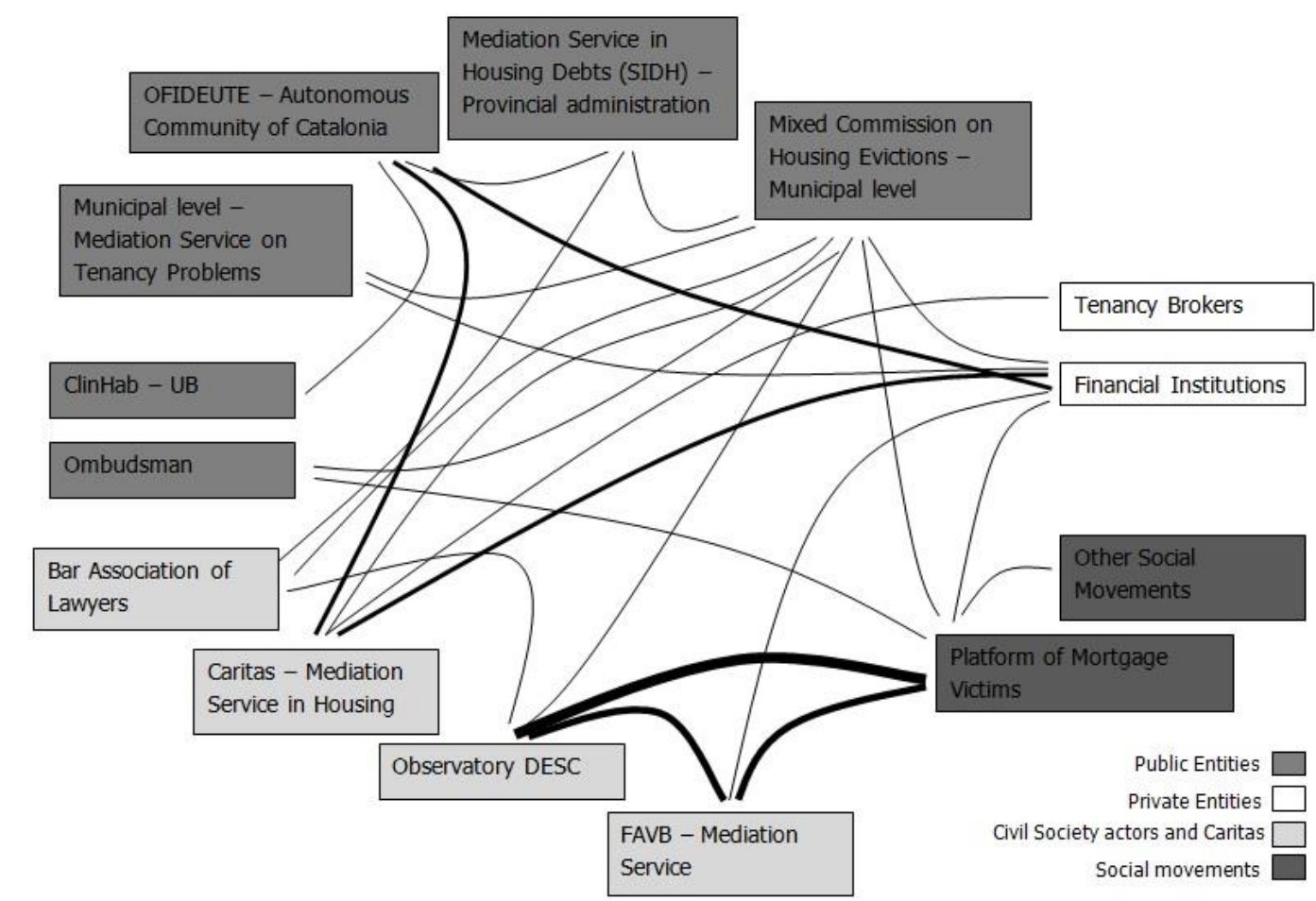

\subsection{Multi-level governance: up-scaling and the relation between PAH and institutions at other scales}

The political actions of the PAH have influenced governance by pushing for the creation of new mechanisms for collectively negotiating housing debts with financial institutions. It has also politically influenced new local and regional regulations for access to housing for mortgage victims. By reframing the issue as a collective instead of an individual debt problem its innovative actions have contributed to new ways of conceptualizing and approaching policy problems. While governments have used an 'individual approach' the PAH has focused on collective responses to social problems (Pradel et al., 2013). Moreover, by operating at multiple levels (from the local to the European) the PAH movement has denounced the lack of transparency of policy making. PAH has used different organizational tools and networks to generate opportunities for gaining relevance in a multi-level governance context. It has achieved legitimacy and exposed the inaction of political parties to a broad situation of social injustice. It has reached European institutions and has thus proved to be a very successful political movement.

In late 2011 the existing PAH local platforms had a first general assembly constituting a national federation (Colau \& Alemany, 2012). This up-scaling of the PAH platform coincided with the development of initiatives at the regional, national and European scales. 
We have already referred to actions at the regional level in Catalonia and in Andalusia. The Catalonia and Valencia Communities have agreed, moreover, with the Judiciary for Social Service to be informed of court rulings on evictions in order to coordinate actions. Interaction between $\mathrm{PAH}$ and the national government and parliament has not been easy. The national government has constrained the actions of $\mathrm{PAH}$ by trying to de-legitimise their campaigns. However, public opinion and pressure from European institutions forced the central government to introduce a change in the law to alleviate mortgage payments for families in extremely vulnerable conditions.

The greatest impact of the PAH actions on governance was at the European scale. The Europeanization of the Spanish housing crisis occurred when a Spanish lawyer asked a preliminary question at the European Court of Justice in a case in which Mohammed Aziz would be evicted from his home in a process wherein he was unable to defend himself in court. The Spanish lawyer also asked Court how the disequilibrium should be interpreted when contractual clauses were not negotiated individually with the contractor. The Advocate General of the ECJ answered that the national judge should interpret the abusive character of the clauses. On these bases the mortgage contract can either be invalidated or undone.

The ECJ ruling on 14/03/2013, public pressure, and support for the People's Legislative Initiative (ILP) - drafted by the PAH movement - obliged the Spanish government to take the ILP in consideration and to modify the Mortgage Law and Civil Procedure to adjust the imbalance between creditor and individual debtor. On May 14 the Spanish Parliament voted a new law to "reinforce the protection of mortgage debtors". This new standard still leaves very little leeway for lawyers and judges. Only under very strict and extreme conditions is debt settlement is allowed. However, the modification of this law and the internationalization (up-scaling) of the problem have led to social innovation in power relations between mortgage debtors and creditors. Moreover, the ECJ judgment gives more autonomy to Spanish judges to decide on abusive clauses and abusive interests on arrears. A number of judges have used this autonomy to rule against evictions.

\subsubsection{Ruling European Count of Human Rights. (16/10/2013)}

A court hearing in Girona ordered the eviction of a house occupied by the PAH movement. This house, owned by the national 'bad bank' SAREB, housed 43 mortgage victims. When 16 families were ordered to leave the building their lawyer appealed the ruling. The European Court of Human Rights decided that the court decision conflicted with the international right on housing and postponed the eviction at least one month, or until the authorities can offer alternative lodging. As a result of this ruling of the ECHR, the PAH and their demands gained legitimacy.

\subsubsection{European Central Bank}

The European Central Bank pointed out in a recent statement signed by its president, Mario Draghi, directed to the Spanish government that they should provide a broader regulative context than the limited adjustments made so far. The recommendation of the ECB president is that the Spanish government should address the underlying causes of problems related to the mortgage loans and should try to avoid mortgage foreclosures 
insofar as possible, while keeping up the proper economic incentives and avoiding moral hazard.

\section{Conclusions}

This paper presents a case of social innovation by organized citizens fighting for social justice. The impact of the financial and economic crisis in Spain has had a very specific feature: the loss of homes for thousands of families over a very short period of time. The scale of the social crisis created by a financial crisis partly explains the emergence of a bottom-up collective response.

The PAH movement developed with a very broad social base. Family members affected by the loss of their homes joined the movement becoming active members creating a horizontal web of relations based on community support and solidarity. Their actions provided information and knowledge to citizens to deal with evictions but also to confront financial institutions. With local public administrations the PAH movement has acted as a pressure group for institutional action supporting citizens, including changing practices and legislation.

One characteristic of a successful social movement is visibility. Our research shows that the PAH movement achieved considerable visibility in the public sphere over a short period of time. This resulted from the presence of the movement in the media showing the human, concrete suffering caused by instances of social injustice. However, the presence of the PAH actors in the public sphere could not have been possible without systematic organization at the city neighbourhood level.

Our analytical perspective shows the emergence and consolidation of a successful social movement as an example of social innovation because it aims beyond denunciation and protest to actually providing (facilitating) material resources not provided by the market or the state. The failure of public and private institutions in Spain to provide solutions for the loss of homes created the opportunity for the socially innovative political action of the PAH movement. However, social actors involved in socially innovative practices find important opportunities and constraints in realizing their projects. Many of these opportunities and constraints are related to how institutions respond to innovation. But also to how civil society organizations and social movements approach institutions.

The institutionalization of socially innovative practices is crucial for socialinnovation projects to last and for achieving long-term effects. Institutionalization is mainly recognition of objectives and actors as legitimate and the support of public authorities. Institutions may be receptive at first to bottom-up initiatives and then incorporate some of the innovative practices into policy making. In the case of the PAH movement in Barcelona and Catalonia local institutions were open to develop mechanisms of negotiation with financial institutions to deal with the mortgage crisis. Similar processes happened in other cities of Spain. However, cooperation between the PAH movement and institutions remained ambiguous. Although they shared information and participated in formal housing commissions and cooperate in some instances the PAH kept an openly critical approach to insufficient policy action of administrations. We 
have argued that this is a case of bottom-linked social innovation on the bases of existing tension, cooperation and dialogue between public institutions and the PAH movement.

Finally, the impact of mobilization on international institutions through pressure on the Spanish parliament to change legislation is a demonstration of the strength the PAH movement. Often institutionalization of this kind involves "up-scaling" of social innovation in multilevel governance. Higher levels of governance beyond the local carry responsibility for maintaining/improving universal access to welfare resources. This question is particularly relevant in the current economic and political context of welfare state retrenchment.

\footnotetext{
i The paper results from research conducted under COST Action IS 1102 during 2012 and 2013. ii GPD per capita rose from $72.5 \%$ in 1985 to $97.2 \%$ in 2004 compared with EU15 members.
}

iii Large real- estate companies, together with banks, companies involved in housing price appraisal and notaries most influenced housing price inflation and creation of the bubble because of their large presence in the real-estate sector.

iv Ley de Enjuiciamiento Civil art. 579/698 (2000-PP). Art. 579 of the Civil procedure says "in case of the auction of the property mortgaged or pledged, and where the product is insufficient to cover the claim, the claimer may request the initiation of (mortgage) executions for the missing amount of the total debt, and the execution will continue according to the ordinary rules applicable to every execution".

v Exact number of initiated mortgage foreclosures during 2008-2012 in Spain: 415117; in Catalonia: 79699 (C.G.P.J.) vi Decreto de 8 febrero 1946, Ley Hipotecaria

vii Ley de Enjuiciamiento civil, art. 1911: "del cumplimiento de las obligaciones responde el deudor con todos su bienes, presentes y futuros"

viii Art. 695 of Ley de Enjuiciamiento Civil limits the possibilities of plea to only calculation errors or liquidation of debts.

ix The main promoters of the Platform were familiar with housing problems in Spain and had already founded a lowprofile social movement "V por Vivienda" in 2006 that focused on the inaccessibility of housing for low income population, especially young people.

$x$ Deprivation of human needs: material and currently also democratic participation.

xi The workshop was held on 17th september 2013, http://www.cost-is1102-cohesion.unirc.it/nationalpages/spain/barcelona-action-unit

xii Plataforma de Afectados por la Hipoteca, http://afectadosporlahipoteca.com, consulted on 2/04/2013

xiii The General Council of the Judicary compiles the most accurate data on the Spanish mortgage foreclosures and evictions. However, the notaries, property registrars and the National Bank of Spain all report different data.

xiv http://www.metroscopia.org/datos-recientes/tag/metroscopia-dinamico/PAH, consulted in march 2013

xv CIS, Centre of Sociological reseach,

http://www.cis.es/cis/opencms/EN/11_barometros/Indicadores_PI/documentos/serGobOpo1.html

xvi El País, 30/03/2010 http://economia.elpais.com/economia/2010/03/30/actualidad/1269934384_850215.html

xvii Ley del Derecho a la Vivienda 18/2007 : this law was established under the left coalition government.

xviii The list of the Municipalities that have approved the motion can be found on

http://afectadosporlahipoteca.com/mociones-ayuntamientos/ and El País, 23/02/2014

http://politica.elpais.com/politica/2014/02/21/actualidad/1393010178_488272.html

xix A left majority: IU \& PSOE, voted on 09/04/2013

xx Real Decreto Ley 27/2012, 15 noviembre, Medidas urgentes para reforzar la protección a los deudores hipotecarios xxi Ley $1 / 2013$, de 14 de mayo, de medidas para reforzar la protección a los deudores hipotecarios, reestructuración de deuda y alquiler social

xxii By means of analysis of 470 articles on the PAH published in el País between 01/2012 and 04/2013

xxiii The initiative of this new project was Carmen Trilla's, secretary of housing at that moment.

xxiv Ofideute has agreed with financial institutions to have a single contact person, mostly in the risk department, to whom Ofideute sends the debt settlement proposals of each case they receive.

xxv Two other people who formed the nuclear group of Ofideute: Joana Suñer and a financial expert have also moved from Ofideute to Caritas, apparently because of a lack of funding.

xxvi However, financial institutions are not obliged to accept mediation in case of payment arrears on mortgage contracts: people depend entirely on the goodwill of the financial institution in each particular case. This is the case for each mediation service. 
xxvii http://www.bcn.cat/consorcihabitatge/ca/consell-habitatge.html, accessed december 2013

xxviii http://www.conselldeciutat.cat/es/page.asp?id=30, accessed december 2013

xxix List of members of ABSH: http://www.bcn.cat/consorcihabitatge/es/consell-habitatge.html

xxx In 2012, 1.972618 euro (64\% of the family assistance total) went to family aid related to housing problems.

xxxi Forty representatives of social organizations, financial institutions, legal institutions and the public administration gather to communicate and relate the experiences and practices from the point of view of their field of action.

xxxii Defensor del Pueblo, Crisis Económica y deudores Hipotecarios,

http://www.defensordelpueblo.es/es/Documentacion/Publicaciones/monografico/Documentacion/informe_deudores_hip otecarios.pdf

xxxiii The PAH movement used the ombudsman office to submit complaints against the administration and cooperate on the formulation of recommendations.

xxxiv Sindic de Greuges, julio 2012, Rafael Ribó Massó

http://www.sindic.cat/site/unitFiles/3334/Informe\%20reestructuracion_deuda_hipotecario.pdf 